\title{
Mostly 'men in suits' The ASEAN summit and integration as news in Southeast Asia
}

\begin{abstract}
This article is a preliminary examination of how Southeast Asian media frame the regional integration of Association of Southeast Asian Nations (ASEAN) as a news topic. Without grassroots engagement, the ASEAN integration will inevitably fall short of its grand objectives, and crucial to building grassroots engagement is media coverage capable of building audience interest and appreciation. Based on articles published during the major ASEAN summit events in 2018, the authors identified resonant themes in the reportage and discussed these vis-à-vis the documented character of the different media environments in the region. It was found that the axis of the reportage is the declarations and actions of the heads of state, with very few human interest and context-building stories that would have built audience engagement in what is otherwise an affair revolving around 'men in suits'. Moreover, the journalistic emphasis on consensus and state initiatives reflects continuing adherence to the tenets of the development journalism framework, but this can also be interpreted as the dominance of 'prominence' as a news value (i.e. stories are framed according to the gestures of prominent individuals). These findings call attention to the need for re-thinking reportage on potentially high-stake phenomena such as the ASEAN integration.
\end{abstract}

Keywords: ASEAN, Asian values, content analysis, development journalism, media studies, Southeast Asia

\section{PAULINE GIDGET ESTELLA}

University of the Philippines, Diliman

Technische Universität IImenau

JONALYN PAZ

Far Eastern University, Manila

\section{Introduction}

-HE SUCCESS and relevance of the Association of Southeast Asian Nations (ASEAN) integration is a subject of a winding debate (Chanco, 2018; Desker, 2015; Doody, 2018; Heydarian, 2015; Menon \& Melendez, 2016; Nair, 2018). On one hand, this integration of the 10 states in Southeast Asia (for instance, through development of economic policies harmonious with those 
of other member states, if not shared by all of them) is momentous because of its capacity to generate game-changing reforms in broad political and economic spheres (ASEAN, 2013; Kesavapany, 2015). On the other, it has been described as 'hollow regionalism' (Heydarian, 2015), as some authors cast doubt on its relevance to the greater population (Desker, 2015; Heydarian, 2015). For scholars like Desker (2015), ASEAN integration remains an 'illusion' with 'little impact on the lives of most people in its 10 member states [that] have diverse political, economic and legal systems and are at different levels of economic development'. What is crucial to examining the regional integration is robust media coverage, one that will allow the audience to fully grasp how this translates to their everyday lives. This begs the question: how does the media in Southeast Asian countries treat ASEAN integration as a news topic?

\section{The debate on ASEAN relevance and progress}

The regional formation, created through a declaration dated 1967, is comprised of 10 member states (Brunei Darussalam, Cambodia, Indonesia, Laos, Malaysia, Myanmar, Philippines, Singapore, Thailand and Vietnam). It is originally a 'political bloc and security pact' established shortly after the Vietnam War, but has evolved to focus on an "ambitious" economic agenda (Melon \& Melendez, 2016, p. 681). Although the 1967 declaration gave a sense of unified vision and community, the heads of state and other policy makers felt the need to organise ASEAN into a more 'politically cohesive' and 'economically integrated' community (ASEAN Secretariat, 2017b, p. 2). The ASEAN leaders in 1997 formalised this initiative through the declaration of 'ASEAN Vision 2020', which emphasises the formation of the "ASEAN Community" as a culminating goal. In 2015, five years before the target year, the ASEAN leaders formally launched the ASEAN Community, which is still in the process of integration.

The integration initiative is guided by the Economic, Political-Security and Socio-Cultural Blueprints ('three pillars' of integration), and the objective now is to meet critical targets by 2025. The ASEAN policy-makers 'envision' a 'rules-based' and 'cohesive' community of 'shared values and norms' (ASEAN Secretariat, 2009, p. 2), with narrowed development gap, and characterised by 'free movement of goods, services, and investments as well as freer flow of capital and skills' (ASEAN Secretariat, 2013). Another core element of a fully established ASEAN community (therefore another goal in the list) is '[integration] into the global economy', not just within itself (ASEAN, 2017b, p.3).

In the latest monitoring report published by ASEAN (ASEAN Community Progress Monitoring System), the integration initiative appears to be meeting its targets based on select indicators (see ASEAN Secretariat, 2017a). The ASEAN Secretariat (2017a) reported that 'the region has undergone significant economic activities with improved trade in goods and services, increased foreign direct 
investments (both intra-ASEAN inward and from the rest of the world), heightened innovation, enhanced [information and communication technology] and transport connectivity' (p. 10). However, 'more policy attention' is required in other areas such as employment and 'building resilience to external risks' (p. xiv).

For some authors, there is a need to take these progress reports with a grain of salt (Das, 2012; Menon \& Melendez, 2016). For instance, the ASEAN Economic Community (AEC) 'Scorecard', which the ASEAN uses as its own measurement tool, relies heavily on 'self-assessment' against the means (priority actions and milestones) rather than the end of the AEC (Menon \& Melendez, 2016, p. 684). Furthermore, little is known about how other regions in individual countries are faring against AEC goals, as the measurement tool is 'glossing over significant challenges to implementation' in the individual countries (Menon \& Melendez, 2016, p. 683).

Other authors have expressed their scepticism to these 'accomplishment reports' more strongly (Dosch, 2015; Desker, 2015; Kurlantzick, 2014). Dosch (2015) asserted that the 'current approach to monitoring and disseminating data on regional economic integration is largely driven by political motives and incentives', specifically the need to show the public that 'substantial progress' is being made (p.3). Desker (2015) went as far as to say that there is 'hardly any ASEAN mindset' among the ASEAN population, meaning there is a lack of consciousness as ASEAN citizens rather than just citizens of their respective nations (even a lack of awareness of the ASEAN integration).

Desker's assertion is not without rebuttal. Kesavapany (2015) wrote that ASEAN integration is not merely an illusion-it is a 'work in progress'. He explained that it is incorrect to describe the integration as a failure because some milestones cannot be simply dismissed, an example of which is the fact that 'the region has lived in peace in the last five decades' and that countries with previously 'little economic significance in the region' developed a more robust economy after joining the formation.

But the relevance of the ASEAN integration cannot be decided simply by clashes in scholarly perceptions - it is decided by the perceptions of the primary stakeholders: the 600-million ASEAN population. An important question to ask, therefore: What are the prevalent content themes in the media coverage on ASEAN integration in Southeast Asia, and is there substantial content that provides the necessary context for the layman? Is there substantial human interest themes in the stories that could help build audience engagement and appreciation?

\section{The ASEAN beat and the lack of empirical research on ASEAN newsmaking}

Son (2017a) wrote that ASEAN news, although in many ways 'Southeast Asia's biggest running story', ranks 'low in the priority list' of newsrooms across Southeast Asia. She added that quite a number of news managers and editors believe that ASEAN news does not engage the audience as much as other top- 
ics do, she added, and this is problematic because 'if the ASEAN Community's arrival is widening the space where ASEAN affects its constituency's lives, the scope that media gives to dissecting this...needs to expand as well'. Chongkittavorn (2015) also observed that the media is still 'disconnected from the ASEAN Community', and like Son, he believes that the media carries the burden of building active engagement among the over 600 million ASEAN citizens.

Indeed, it appears that much work has yet to be done on increasing awareness on ASEAN affairs based on available figures. In a 2012 survey commissioned by the ASEAN secretariat, 81 percent of respondents said they are 'familiar' with the general concept of ASEAN, but 76 percent 'lack a basic understanding' of its objectives. The respondents include 261 business leaders and 2200 from other sectors. Up-to-date data on ASEAN awareness is highly lacking in many member countries.

Son (2017b) suggested ways of taking ASEAN news closer to the wider audience - apart from business and political leaders and others at the helm of the integration initiatives - such as new story-telling techniques that could build human interest. Chongkittavorn (2015) believes in the same idea: 'ASEAN journalists must focus on the aspirations of common folk...media communities in ASEAN must create among their citizens a sense of ownership of this Community'.

But Son's (2017) and Chongkittavorn's (2015) observations on media coverage have yet to be validated by empirical means. This is the research deficit that we aim to address. How exactly does the media in Southeast Asian countries portray ASEAN affairs? What are the recurring themes in journalistic content and which content is given emphasis?

\section{The character of journalism in Southeast Asia}

In attempting to empirically determine news values in the coverage on ASEAN integration, it is necessary to be familiar with the literature trends on the 'identity'-so to speak-of journalism in Southeast Asia. Three resonant trends in related studies are: 1. the 'global anomaly' that is the tightly-controlled media environments existing alongside market-driven economic growth and 'authoritarianism' (or elements of it) as in the case of Singapore and Malaysia (George, 2003, p. 251); 2. 'development journalism' as the dominant model in these countries as well as in the low to middle income closed systems, like Vietnam and Cambodia (Wong, 2004, p. 26) and 3. the ethical and quality issues arising from commercialisation of media in partly free systems.

The 'global anomaly' that is development journalism in an advanced economy George (2003) debunked the idea that a tightly controlled media system is only a transient phase and that it will eventually gravitate toward the liberal framework once the economy becomes highly developed. According to George,

196 PACIFIC JOURNALISM REVIEW 25 (1 \& 2) 2019 
many have underestimated 'the power of ideology, and especially economic incentives, as tools of cooptation and control' (p. 25). The government of Singapore, for example, was able to use its media system in furthering its economic agenda through what George (2003) called 'calibrated coercion'. The repertoire of regulation of the Singaporean government moves away from 'flamboyant punishments such as imprisoning journalists and banning publications, towards more behind-the-scenes controls that create the conditions for self-censorship' (George, 2003, p. 94).

George (2003) explained that on one hand, media plays an indispensable role in market growth: 'markets require efficient media, in terms of both the information that they circulate as well as the technological means for circulating information' (p. 251). On the other, media assumes a role in the 'political and ideological imperatives' of the state and acts as a '[tool] for maintaining political stability' (p. 251). The government's approach is 'narrowly tailored': it treats political expression as a 'special category requiring special management', while other activities of the media are given more legroom 'to respond to market signals' (p. 251).

Stockmann's (2014) and George's (2003) books, on the state-media relations in China and Singapore respectively, illustrated how market forces have helped bolster regime stability, contrary to the assumption that commercialisation of media can lead to its democratisation. In the 'marketisation' of media, even market forces have established their own means of control. Consequently, media freedom in semi-authoritarian or electoral-authoritarian advanced economies are threatened by both market interests and political imperatives.

The governments of Singapore and Malaysia are also the 'most outspoken proponents' of development journalism (Wong, 2004, p.26), which has earned traction among regimes in Southeast Asia. The premise, according to Wong, is 'to have journalism play a central role in disseminating governmental or national policies to inform and educate the masses as well as mobilise them for the concerted effort at bringing about economic development' (2004 p. 26).

\section{The debate on development journalism}

Indonesia, Singapore and Malaysia were among the 'well-known practitioners' of development journalism by the mid-1990s (Wong, 2004), although the journalists of Indonesia, by mid-2000s, are starting to see themselves 'objective disseminators of the news and not as political actors or agents of development' (Hanitzsch, 2005, p. 1). Generalist media in the Philippines, however, has long been operating largely in a liberal-adversarial style of journalism even before the 1990s. This is ironic given that the development journalism paradigm originated in the Philippines, where a group of academics established a development-centered communication programme as they 'found the Western liberal media too much driven by sensationalism and commercialism at the expense of socially 
important news about community projects, rural developments, efforts to address poverty, etc.' (Wong, 2004, p. 26).

The discussion on development journalism, or what Loo labeled as 'compliant journalism' (p. 14) cannot be divorced from the idea of so-called 'Asian values' (see Hsiung, 1985; Tay \& George, 1996; Wong, 2004), the elements of which include 'family above self, community above individual, constructive engagement as opposed to confrontation', and which rests on the 'consensusseeking instinct' (Wong, 2004, p.27). The governments in Southeast Asia that embrace the development journalism approach are, not surprisingly, also the ones that espouse the value of consensus as the core of national ideology.

These values of harmony and supportiveness supposedly legitimise the goal of the development journalism model: promote 'political stability' and state agenda for national development (Latif, 1996). This is in fact codified in the ASEAN model of journalism, which underscores preservation of regional harmony, national identity and support for government initiatives (Menon, 1998; Pak, 1997).

The journalistic emphasis on these Asian values is strongest in Southeast Asian newspapers, according to Massey and Chang's (2002) study on 'hard' news stories in select online newspapers in Asia. The authors found that the Asian values of 'supportiveness' and 'harmony' were most visible in Singaporean, Bruneian and Malaysian newspapers, and they also made an interesting conclusion: these Asian values are "not uniformly Southeast Asian journalistic norms' but a 'phenomenon of closely controlled national press systems' (p. 999).

This emerging universal set of news values was also discussed in a more recent content analysis on Singaporean news (see Cenite, Chong, Han, Lim, $\&$ Tan, 2008). In this study, the authors found that Singaporean press coverage during the 2006 elections operated within the development journalism model as it did for decades, but only partly. More emphasis was given on 'game frames' (competition among candidates and parties) rather than 'issue frames', which the researchers attributed to the need to maximise revenues. Game-framed coverage contains the elements of conflict and novelty that could sustain reader interest (Benoit, Stein, \& Hansen, 2005; Cenite et al., 2008; Hahn \& Iyengar, 2002). In other words, this is a unique result of commercial imperatives that news firms cannot ignore despite operating within tight government control. However, the coverage was still heavily lopsided in favour of the ruling political party, which the authors interpreted as a gesture rooted in Singapore's 'perpetual' development journalism model (p.280).

As an outcome, the watchdog function that is a normative feature of journalism in the West becomes subordinate to the promotion of unity and state agenda (or is ultimately omitted). For this reason, the development journalism model has been heavily criticised in journalism discourse. Some critics described it as merely 'government say-so journalism' (Lent, 1978, p. 1), as it relies mostly on 
government sources. Ali (1996) wrote that it gives authorities the opportunity to 'hijack' it under the pretext that developing nations cannot afford free and critical press (p.148).

Some authors wrote that this paradigm generates self-censorship and 'overly cautious journalism', as texts deemed as a threat to national interest or contradictory to state ideologies and policies were omitted or 'blacked out somewhere along the news production chain' (Loo, 2013, p.13; Wong, 2004). Loo (2013) explained that the self-restraint in journalism is not just borne out of professional ideology but is also a consequence of acts of violence against them: 'history of defamation suits by politicians, unexplained sackings for challenging the status quo, and closure of news organisations under media laws' (p. 50). This selfcensorship is also observed even in countries with media systems that are not tightly controlled, as in the case of Philippines, where a sample of journalists reported a degree of self-censorship due to internal and external pressures (Estella, 2018). This documented media situation in Southeast Asia should explain the rankings of almost all of its countries in the World Press Freedom Index, prepared by non-government organisation Reporters Without Borders (2018), in the past few years: consistently at the bottom third of the scale.

Some scholars pointed out that development journalism cannot be simply reduced to one-sided reportage and offered "more benign" interpretations (Kalyango et al., 2016, p.3). At its core, this practice highlights news that would allow people to understand and participate in development initiatives down to the grassroots level (Anand, 2014; Aggarwala, 1979; Richstad, 2000; Shah, 1988). Hence, as Kalyango et al. (2016) noted, it is 'interventionist, developmental, and educational' (p.3) -reporters are socialised as agents of change or contributors to societal progress. For Richstad (2000), development journalism is a cooperation between the government and the Fourth Estate, not necessarily the media being subsumed as the propaganda arm of the state. Other proponents of development journalism believed that this approach gives ample room to issues that are often ignored by mainstream generalist media simply because they do not 'sell' to the general public.

\section{The profit motive and ethical lapses}

The heads of state in authoritarian and semi-authoritarian systems have attempted to justify tight media regulation by tendencies to focus on triviality and to sensationalise news as dictated by profit motive (Karppinen, 2015; Loo, 2013; Wong, 2004). Related literature has shown this to be true to some extent.

In Indonesia, for instance, 'excessive commercialism' was said to have spawned media corruption and other forms of ethical issues (Loeqman, 2003, as cited in Triputra, 2017; Marzuki, 2013). According to Marzuki (2013), the Indonesian industry has turned into a 'free-for-all overnight profit-making media market', as some journalists have left the outlets due to conflicts with media owners (p. 145). This is congruent with the findings of Tapsell (2012), whose study is 
based on 80 interviews with Indonesian journalists. The respondents admitted having varying degrees of 'self-censorship' and their publications were 'being used to promote their owners' interests' (Tapsell, 2013, p. 241).

\section{Research questions and scope of the study}

This research looks into the coverage on the recently concluded ASEAN special summit in Australia and the annual summit in Singapore, which were held March and April 2018, respectively. We analysed all articles published online from March to May last year by select news firms from three countries in Southeast Asia: Philippines, Cambodia and Singapore.

The countries were chosen as representative environments of Southeast Asia largely based on dimensions proposed by Hallin and Mancini (2004): role of the state (or media-state dynamics), prevalent role perception of journalists and structure of media markets, balanced by a consideration of other dimensions such as national income and income distribution and recent political developments that call attention to the media landscape in the country (e.g. number of journalist killings and harassment cases). The choice of countries also provides representatives for each of the three broad categories of media environments as identified in several works such as that of Loo's (2013): tightly controlled under authoritarian/ Communist or Socialist political systems (Cambodia); tightly or partly controlled under authoritarian/semi-authoritarian systems (Singapore) and free or partly free systems (Philippines).

Another factor considered in the choice of countries is the presence of news media that publish in English (to avoid possible loss of meaning in translation) and which have a significant, if not the largest, circulation and user engagement levels. The primary research question is obviously:

RQ1: What content themes were recurrent or given emphasis in the coverage on the ASEAN special summit in Australia (March) and the annual summit in Singapore (April)?

We also included all articles related to ASEAN published within the months of March to May, including those that were presumably published as build-up or follow-stories (but not accounts of ASEAN summit events). It has to be noted that the study covers only stories on the most recent ASEAN summits held March and April, as well as all the other stories published within that time period. Other ASEAN stories outside the timeframe are excluded. As this is also a comparative study, another question that we aim to address is:

RQ2: How does the coverage on the ASEAN summits vary across the news sites vis-à-vis the character of the media systems in which they belong? 
Given what was discussed on the types of media systems in related literature, it is important to determine whether or not specific paradigms as documented in existing studies still figure in ASEAN coverage, thus the following research questions:

RQ3: How does the development journalism model manifest its character in the ASEAN coverage of Singaporean and Cambodian news firms (if it does)?

RQ4: What content themes are prominent in news content published by firms in a partly free media system (Philippines)?

\section{Methodology}

The websites of mainstream news firms with significant reach and user engagement in three Southeast Asian countries served as the loci of this study: $A B S$ CBN News and GMA News Online (Philippines), Phnom Penh Post and Khmer Times (Cambodia), and The Straits Times and Today (Singapore).

Philippines' ABS CBN has a 46 percent average audience share as of February 2018, while GMA has 34 percent (Kantar Media, 2018, as cited in ABS CBN News, 2018). Phnom Penh Post and Khmer Times, meanwhile, are Cambodia's leading English dailies, with the former having a circulation rate of over 21,500 circulation copies per day and the latter 6000-8000 copies per day, according to the most recent circulation figures available (Media Ownership Monitor Cambodia, 2015). In Singapore, The Straits Times leads the roster of dailies, with a readership of 1.23 million per day as of 2016, followed by Today with 548,000 (Nielsen Singapore, 2016, as cited in Today, 2016).

A total of 112 articles were analysed in this study, including hard news stories, features and opinion pieces based on the following criteria:

1. Must be published between March to April 2018, the months in which the ASEAN Summit 2018 and the special summit in Australia were held, and

2. Must be part of the coverage on ASEAN Summit 2018 and Special Summit in Australia, or at least related to ASEAN affairs (e.g. build-up stories prior to the summit).

Those that were not written in English and offered no equivalent translation were excluded. We obtained data online using the digital archive services of each media outlet. The collected articles were then coded and tabulated using Atlas.ti software. We used the coding analysis scheme proposed by Saldanha (2009). A code, according to Saldanha (2009), is 'a word or short phrase that symbolically assigns a summative, salient, essence-capturing, and/or evocative attribute for a portion of language-based or visual data'.

We also used Strauss and Corbin's (1998, as cited in Gray, 2004) simple coding process in this study. The study employed open, axial and thematic coding process 
in disaggregating the data and analysing the result. The essence and attribute of the data were given premium in choosing and assigning the codes.

Though some of the codes were taken in vivo, all primary codes were treated as open codes and were fractured and re-fractured into units until the underlying patterns emerged. Based on their similarities and relationships, these aggregated components were grouped into categories. The results were then fused to produce the major themes and sub-themes. It should be said that these codes inevitably overlap with each other (as meanings overlap in texts), so each unit, for example, can contain multiple codes.

\section{Findings}

A total of 28 codes were generated. These are composed of five major themes and 23 subthemes. Some of the codes are present in the sampled articles in vivo (i.e. migration, war on drugs, resiliency, trade wars etc.) while others were taken from the existing related literature (i.e. consensus and harmony, economics, conflict etc.).

\section{Mostly about 'men in suits': The lack of human interest angle}

The 'Heads of State' (the activities, quotes, and background of and other related information on the ASEAN leaders) is the most recurring theme in the stories published by the select news websites. More than 40 percent of the content in all articles are about the affairs of the heads of state, their statements and mentions of them. The breakdown of the major themes can be seen on Table 1 .

In many of the stories, the news angle, as defined primarily in the lead paragraph and headline, is what was said and what was done by what Son (2017) calls as 'men in suits'. The primary agent is the head of state (or his or her minister) and the emphasis is on what he or she said or did. For instance, many articles published by the Singaporean news firms (The Straits Times and Today) are speech stories anchored on the statements of the Singaporean prime minister or the minister for finance. The Philippine media in this study also framed the majority of their articles according to the actions and statements of the Philippine president (e.g. the headlines 'Duterte leaves for Singapore to attend ASEAN summit', 'Duterte in India for ASEAN commemorative summit', 'Duterte eyes stronger PH-India military ties', among others) at a rate higher than those of Cambodian and Singaporean media. Cambodian news firms were no different in their emphasis on the heads of state, but the news outlet Phnom Penh Post framed their stories in a manner vastly different from Khmer Times did (to be discussed later in this section). Table 2 compares the distribution of content across countries based on the selected news firms.

The dominance of the 'Heads of State' theme is consistent across countries, but the framing of ASEAN leaders varies from one news firm to another. For example, Philippine coverage presented heads of state mostly as problem-solvers-ASEAN 


\begin{tabular}{|c|c|c|c|}
\hline Major themes & $\begin{array}{c}\text { Theme } \\
\text { percentage }\end{array}$ & Subthemes & $\begin{array}{l}\text { Subtheme } \\
\text { percentage }\end{array}$ \\
\hline \multirow{5}{*}{ Heads of State } & \multirow{5}{*}{$42.76 \%$} & HoS as economics & $.11 \%$ \\
\hline & & HoS as oppressors & $2.05 \%$ \\
\hline & & HoS as problem solvers & $2.78 \%$ \\
\hline & & HoS as vanguards of security & $1.30 \%$ \\
\hline & & Mentions and other quotes & $36.52 \%$ \\
\hline \multirow{4}{*}{ Economics } & \multirow{4}{*}{$22.06 \%$} & Connectivity and mobility & $2.74 \%$ \\
\hline & & Economic challenges & $1.37 \%$ \\
\hline & & Economic opportunities & $17.56 \%$ \\
\hline & & Innovation in business and finance & $.40 \%$ \\
\hline Consensus & $17.30 \%$ & Consensus-seeking and harmony & $17.30 \%$ \\
\hline \multirow{9}{*}{$\begin{array}{l}\text { Conflict and } \\
\text { external threat }\end{array}$} & \multirow{9}{*}{$13.7 \%$} & Cyber attacks & $1.08 \%$ \\
\hline & & Crisis in Myanmar & $1.51 \%$ \\
\hline & & Political crackdown & $2.99 \%$ \\
\hline & & South China Sea dispute & $2.99 \%$ \\
\hline & & Threat of extremism & $.76 \%$ \\
\hline & & Trade wars & $1.51 \%$ \\
\hline & & $\begin{array}{l}\text { Transnational environmental } \\
\text { challenges }\end{array}$ & $.29 \%$ \\
\hline & & War on drugs & $.36 \%$ \\
\hline & & Dissent & $2.20 \%$ \\
\hline \multirow{3}{*}{ Others } & \multirow{3}{*}{$4.18 \%$} & Brief background about ASEAN & $1.44 \%$ \\
\hline & & Migration & $.79 \%$ \\
\hline & & Resilience & $1.95 \%$ \\
\hline Total & $100 \%$ & Total & $100 \%$ \\
\hline
\end{tabular}

leaders working toward resolving conflict situations and averting possible trade wars, negotiating with the Chinese government over territorial disputes, increasing 'coordination to shield countries from cyber-attacks' (ABS-CBN, 2018) and who, in light of transnational crimes, 'have already completed a model for the [ASEAN-wide extradition] treaty' (ABS-CBN, 2018). Singaporean news outlets, on the other hand, emphasised what the head of state says about economic growth and policy ("HoS on economy"), something that is almost invisible in the coverage of Philippine and Cambodian firms. This variance in journalistic emphasis among the frames under the major theme of 'Heads of State' is shown in Table 3. 
Table 2: Cross-country comparison for selected SE Asian news firms

\begin{tabular}{|l|c|c|c|}
\hline & \multicolumn{3}{|l|}{ Distribution of journalistic content (in percentages) } \\
\hline Major themes & $\begin{array}{l}\text { Cambodian news } \\
\text { firms (Phnom } \\
\text { Penh Post and } \\
\text { Khmer Times) }\end{array}$ & $\begin{array}{l}\text { Philippines news } \\
\text { firms (ABS CBN } \\
\text { News and GMA } \\
\text { News Online) }\end{array}$ & $\begin{array}{l}\text { Singaporean } \\
\text { news firms (The } \\
\text { Straits Times and } \\
\text { Today) }\end{array}$ \\
\hline Heads of State & $37.32 \%$ & $58.88 \%$ & $37.38 \%$ \\
\hline Economics & $17.75 \%$ & $10.42 \%$ & $27 \%$ \\
\hline Consensus and harmony & $17.75 \%$ & $15.64 \%$ & $17.66 \%$ \\
\hline Conflict & $28.36 \%$ & $6.76 \%$ & $12.03 \%$ \\
\hline Others & $1.81 \%$ & $8.30 \%$ & $5.93 \%$ \\
\hline
\end{tabular}

In the case of Cambodia, there is a massive difference in content-framing between Phnom Penh Post articles and those of Khmer Times. Phnom Penh Post presented the heads of state, particularly the Cambodian prime minister, as 'oppressors', directly associating them with political crackdown, closure of the independent press and their deliberate dismissal of matters relevant to the common folk. However, this is omitted in Khmer Times, which forwarded the heads of state as problem-solvers. Hence, the framing among Cambodian news sites contains extremes: one framing the heads of state as oppressors (5.07 percent), the other framing them as problem-solvers (3.08 percent). This finding is congruent with the reputation of Phnom Penh Post as a publication that is critical of the Cambodian political regime (Massola, 2018).

Yet, across the pool of articles, the heads of state were mostly presented as problem-solvers and vanguards of security in the region, positively depicted as protectors and leaders working for a change in progress. Interestingly, in a majority of the texts (except those of Phnom Penh Post), little space is given to alternative or critical assertions, or even opinion from non-government entities. The content theme 'Dissent'protests - against human rights violations and other forms of political crackdown - accounts for only 2.20 percent of the total content, with Philippine media not including this type of content. Only Cambodia's Phnom Penh Post has a substantial amount of content coded under 'Dissent' (balanced out by the lack of it in the Khmer Times) at 8.70 percent.

Some may argue that the journalistic emphasis on the heads of state is nothing less than expected given that the ASEAN summits are a gathering of the heads of the state and therefore the coverage should revolve around their affairs shortly before, during and after the event. However, for the common folk to evaluate-let alone be interested in - something as high-profile as a gathering of state leaders or regional integration, the reportage on these events should be balanced by attempts to translate these into terms the audience can understand 


\section{Table 3: The different frames for 'Head of State' content}

\begin{tabular}{|l|c|c|c|}
\hline & \multicolumn{3}{|l|}{ Distribution of journalistic content (in percentages) } \\
\hline $\begin{array}{l}\text { Subthemes under } \\
\text { 'Heads of State' (41.39\% } \\
\text { of the total content) }\end{array}$ & $\begin{array}{l}\text { Cambodian news } \\
\text { firms (Phnom } \\
\text { Penh Post and } \\
\text { Khmer Times) }\end{array}$ & $\begin{array}{l}\text { Philippines news } \\
\text { firms (ABS CBN } \\
\text { News and GMA } \\
\text { News Online) }\end{array}$ & $\begin{array}{l}\text { Singaporean } \\
\text { news firms (The } \\
\text { Straits Times and } \\
\text { Today) }\end{array}$ \\
\hline HoS on economy & - & - & $.18 \%$ \\
\hline HoS as oppressors & $5.07 \%$ & - & $1.70 \%$ \\
\hline HoS as problem solvers & $3.08 \%$ & $6.76 \%$ & $1.47 \%$ \\
\hline $\begin{array}{l}\text { HoS as vanguards of } \\
\text { security }\end{array}$ & $0.72 \%$ & - & $1.88 \%$ \\
\hline $\begin{array}{l}\text { HoS mentions and } \\
\text { quotes }\end{array}$ & $28.44 \%$ & $52.12 \%$ & $32.16 \%$ \\
\hline
\end{tabular}

(Chongkittavorn, 2015; Son, 2017a). For instance, in online platforms, these stories can be interactive narratives discussing the implications of ASEAN resolutions to sectors like workers, women and students, among others.

Son (2017a) explained that 'while summit-shaped stories that look into how declarations are decided, what language was changed, pushed or objected to, say a lot, the story is not complete because the impact of ASEAN's decisions are to be seen and felt outside the airconditioned summit venues'. But what is sorely lacking in the coverage is the 'soft news' and human interest stories that could have discussed the impact of the ASEAN summit proclamations and affairs on everyday lives. As Son (2017b) suggested, it may help if a journalist frames 'a story by asking what our audiences need to know and investigate from there, instead of getting stuck only in what the heads of state and ministers said', a consequence of which is the reportage without the '[voices of] citizens affected by ASEAN's policies or decisions'.

\section{ASEAN and the economic agenda}

Another dominant theme identified in the content analysis is 'Economics' (22.06 percent), encompassing content on the rejection of protectionism in Southeast Asia; free trade among member states and with allies; building infrastructures for mobility and connectivity and innovation in business and finance. Table 4 provides a comparison of content distribution under 'Economics'.

This journalistic emphasis on economic opportunities stemming from ASEAN integration and other affairs is most pronounced in Singaporean texts (27 percent of the content published by The Straits Times and Today), a finding that is consistent with the observations in related studies (see Lehmann-Jacobsen, 2017; Massey \& Chang, 2006). 


\begin{tabular}{|l|c|c|c|}
\hline \multicolumn{4}{|c|}{ Table 4: The different frames for 'Economics' content } \\
\hline & \multicolumn{3}{|c|}{ Distribution of journalistic content (in percentages) } \\
\hline $\begin{array}{l}\text { Subthemes under } \\
\text { 'Economics' (22.06\% of } \\
\text { the total content) and } \\
\text { 'Consensus and } \\
\text { harmony' (17.30\%) }\end{array}$ & $\begin{array}{l}\text { Cambodian news } \\
\text { firms (Phnom } \\
\text { Penh Post and } \\
\text { Khmer Times) }\end{array}$ & $\begin{array}{l}\text { Philippines news } \\
\text { firms (ABS CBN } \\
\text { News and GMA } \\
\text { News Online) }\end{array}$ & $\begin{array}{l}\text { Singaporean } \\
\text { news firms (The } \\
\text { Straits Times and } \\
\text { Today) }\end{array}$ \\
\hline $\begin{array}{l}\text { Economic challenges } \\
\text { Economic opportunities }\end{array}$ & $2.17 \%$ & - & $1.53 \% \%$ \\
\hline $\begin{array}{l}\text { Innovation in business } \\
\text { and finance }\end{array}$ & $0.51 \%$ & $10.42 \%$ & $22.65 \%$ \\
\hline Consensus and harmony & $17.75 \%$ & $15.64 \%$ & $0.41 \%$ \\
\hline
\end{tabular}

The emphasis on economic growth and state proclamations among Singaporean news firms reflects its journalism paradigm as discussed in the literature review section: development journalism. Albeit there are lengthy informative stories on ASEAN initiatives and economic opportunities, these concepts were explained largely through quotes from official sources in Singapore. This is one of the tendencies that characterise the development journalism framework: the media acts a partner of the state in disseminating the government agenda for economic progress. The focus of the Singaporean news firms on economic matters in the reportage also suggests how the Singaporean government views ASEAN affairs and integration: an opportunity to effectuate commercial exchanges and investment relations, to reject protectionism within the ASEAN bloc and to expand business value chains.

The Philippine news firms, meanwhile, did not discuss these economic opportunities and business innovation in the same length as Singaporean firms did. The economic opportunities as reported by ABS CBN News and GMA News Online come in the form of 'business deals' and 'investment pledge' that the head of state - the Philippine president — secured during the summits. However, these economic opportunities were reported as outcomes of the affairs or actions of the head of state - they are newsworthy because they are associated with the prominent figure in the Philippine context.

Content on economic challenges, meanwhile, is significantly less than that on economic opportunities. Cambodian firms reported on these at a slightly higher rate than Singaporean outlets did (2.17 percent versus 1.53 percent), while Philippine outlets did not cover them at all. Therefore, ASEAN integration was generally presented as an enabler of positive developments in economy. 


\section{Continuing adherence to the 'Asian value' of consensus}

The economic opportunities were associated with consensus and cooperation, especially in the texts published by the Singaporean news outlets. Possible conflict among member states or between non-ASEAN superpowers, such as trade wars and territorial disputes, were presented as impediments to economic growth, while consensus is presented as its prerequisite. The theme 'Consensus and harmony', in fact, is one of the strongest across all news firms in this study, with 17.30 percent of the total content coded under it. The Singaporean news firms, for example, published several stories revolving around unity in resolutions and 'reaffirmation' of pledges (e.g. The Straits Times stories headlined 'ASEAN military chiefs reaffirm security pledge' and 'ASEAN+3 finance, bank chiefs vow to resist protectionism' and Today's headline 'Not easy to finalise South China Sea code of conduct, but talks can prevent tensions: PM Lee'). Philippines' GMA News Online also published articles highlighting cooperation between member states (e.g. 'Duterte, Widodo vow to further strengthen cooperation on security, sustainable development').

Furthermore, challenges and conflict (e.g. security threats and South China Sea territorial dispute) were reported as 'work in progress' more than predicaments within the ASEAN bloc.

This prevalence of consensus and its related concepts is reminiscent of Massey and Chang's (2006) finding that the values of harmony and supportiveness are strongest in Southeast Asian reportage, the 'Asian values' central to the development journalism paradigm and peddled by Southeast Asian regimes as a guide for nation-building.

\section{Comparing the character of reportage}

The findings in our content analysis provide a glimpse on the character of ASEAN reportage across and in each of the three countries chosen to represent the media environments of Southeast Asia. The news websites in this studyselected primarily because of their significant circulation rate and audience engagement (and thus huge potential as opinion-shapers) — give journalistic emphasis to 1) what is said and done by the heads of state, 2) economic opportunities and innovation stemming from ASEAN affairs and 3) consensus, unity or cooperation. The figure below is a graphic representation of the dominant themes in each country:

The axis of reportage is the affairs and opinion of the heads of state, such that many of the stories were framed according to what they did in the summits and what they think of ASEAN and related matters. It appears that the news value of 'Prominence' - newsworthiness by association with high-profile individuals or groups - played as a determinant in story choices, particularly in Philippine media, which for the most part treated ASEAN summits as events attended by 


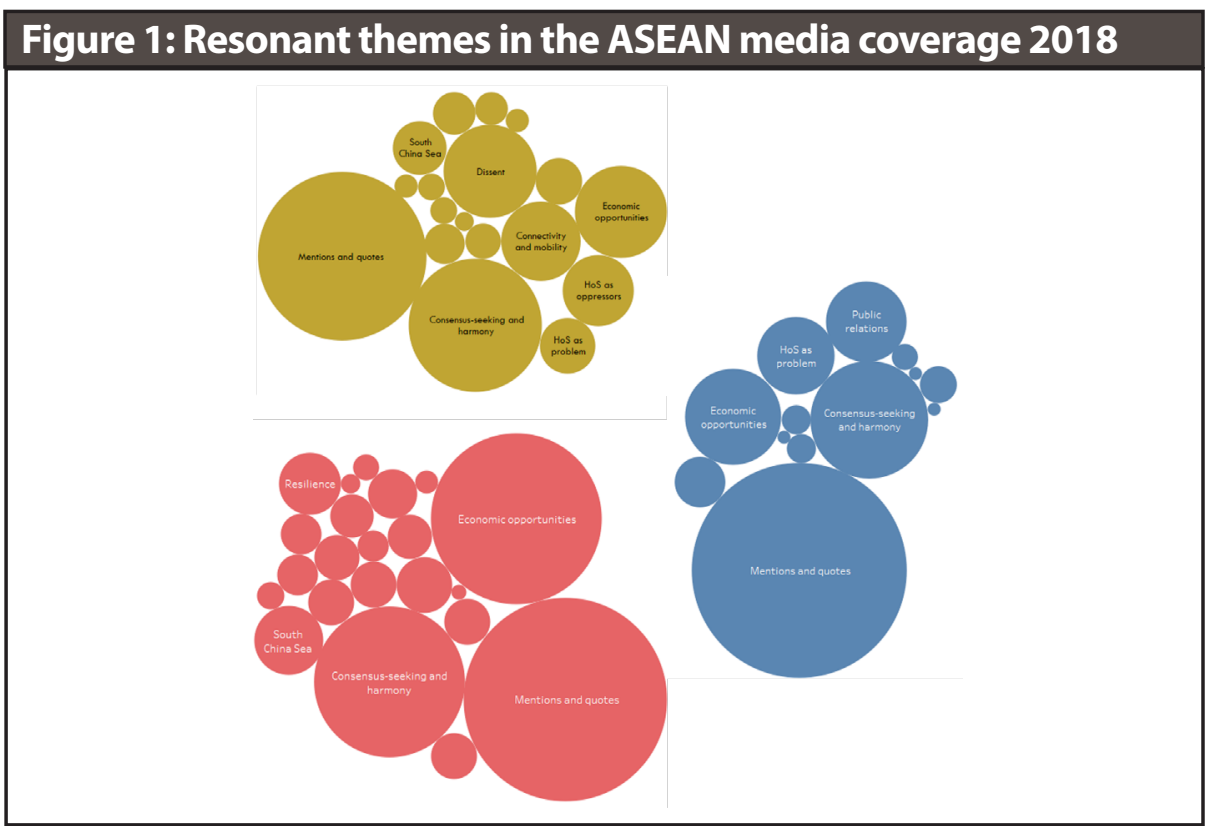

Note: Cambodian news firms (brown), Philippine firms (blue), and Singaporean firms (red). Data visualization was done using Tableau trial version.

the Philippine president and the focus is on his words and actions ('Duterte in ASEAN'). While the Philippines stands as the representative of a partly free media system in this study (with the documented tendency to operate within libertarian press ideals), the reportage on ASEAN affairs centered on what the Philippine president and his team gained in the summit as well as his other declarations. Comprised mostly of short hard news articles, it lacks the discursive stories that could have given more context on ASEAN integration.

Cambodian news firms, meanwhile, also focused on these men in suits, but Phnom Penh Post, in stark contrast with Khmer Times, framed most of their stories on criticisms against the Cambodian prime minister. It also provided the most space for dissenting opinion or opposition. Like Philippine media, however, they also lack the texts that provide more context on ASEAN integration and that give answers to the relevant questions: What does it mean for the common folk? Where is it heading? Where does it stand now?

Phnom Penh Post, despite its large circulation, can be considered an outlier in the Cambodian media system in the sense that it has a track record of publishing articles critical of the Cambodian government. However, as mentioned in the previous section, it has recently been sold to a new publisher, Sivakumar Ganapathy, whose public relations firm, Asia PR, had 'links to the increasingly authoritarian government of Cambodian Prime Minister Hun Sen' (Meixler, 2018), prompting several editors to resign. 
The Khmer Times, on the other hand, published several opinion pieces written by third-party political analysts, and some of these explain possible directions and the dynamics of the member states. However, unlike Phnom Penh Post, Khmer Times barely mentioned the criticisms against the political crackdown allegedly committed by the Cambodian regime, and similar to the Singaporean and Philippine firms, the hard news stories were anchored on the quotes and affairs of official sources.

Singaporean firms in this study included feature stories and opinion pieces that discuss some ASEAN initiatives (e.g. Today's 'What does the ASEAN smart cities network mean for Singapore?'). However, ASEAN affairs were viewed through the lens of government sources (heads of state or other policy-makers) and alternative views were omitted in the coverage. Thus, in the topic of ASEAN integration, the selected Singaporean news outlets served as an extension of government information dissemination, adhering to its supposed role in the framework of development journalism which has long been observed in related studies.

The focus on the actions and affairs of the high-profile individuals, and the insufficient number of contextualising articles answering the most basic question 'What exactly does it mean for the majority of ASEAN population?' could have repercussions on the level of awareness among the 600 million ASEAN citizens. How will the ASEAN initiatives formed at the top be translated to the grassroots level if the citizens were not fully informed (a prerequisite of which is a reportage that engages them and invites dialogue)?

The prevalence of content on economic opportunities and business innovation and the celebration of consensus and cooperation in the ASEAN summit reportage of this year follows the ASEAN model of journalism as discussed in the literature review: a model that describes as a standard the journalism that preserves regional harmony and promotes state initiatives, a framework rooted on the ideals of development journalism.

\section{Conclusion}

This preliminary study provides a glimpse on how Southeast Asian news firms treat ASEAN summits - and in effect the ASEAN integration initiative-as a news topic based on a limited sample. Future research can expand the scope by including more news firms that will represent the different media environments in the region.

Our limited sample can also be expanded to include not just the coverage on ASEAN summits, but also all other ASEAN-related stories. Findings in the content analysis of recent articles can be compared with those on older articles about ASEAN, allowing the researcher to track the evolution (or lack thereof) of reportage. 


\section{References}

ABS CBN News. (2018, March 2). ABS-CBN keeps ratings lead in February: Kantar $A B S-C B N$ News. Retrieved on April 25, 2018, from http://news.abs-cbn.com/business/03/02/18/abs-cbn-keeps-ratings-lead-in-february-kantar

Aggarwala, N. (1979). What is development news? Journal of Communication, 29(2), 180-185.

Ali, O., \& Khan, E. (1996). Roundtable, Media Asia, 23(1), 30-33.

Anand, V. (2014). Development journalism: A catalyst for positive change. ProcediaSocial and Behavioral Sciences, 157, 210-225.

Association of Southeast Asian Nations Secretariat. (2009). ASEAN political-security community blueprint. ASEAN Secretariat. Retrieved on May 22, 2018, from https:// asean.org/wp-content/uploads/archive/5187-18.pdf

Association of Southeast Asian Nations Secretariat. (2017a). ASEAN community progress monitoring system. ASEAN Secretariat. Retrieved on May 22, 2018, from https:// www.aseanstats.org/publication/asean-community-progress-monitoring-system-2017/

Association of Southeast Asian Nations Secretariat. (2017b). ASEAN economic integration brief. ASEAN Secretariat. Retrieved on May 22, 2018, from https://asean.org/ storage/2017/11/AEIB_2nd-edition.pdf

Association of Southeast Asian Nations Secretariat. (2013). ASEAN Economic Community: How viable is investing? ASEAN Secretariat. Retrieved on May 22, 2018, from http://investasean.asean.org/index.php/page/view/asean-economic-community/ view/670/newsid/755/about-aec.html

Benoit, W., Stein, K., \& Hansen, G. (2005). New York Times coverage of presidential campaigns. Journalism and Mass Communication Quarterly, 82(2) 356-376.

Cenite, M., Chong, S., Han, T., Lim, L., \& Tan, X. (2008). Perpetual development journalism? Balance and framing in the 2006 Singapore election coverage. Asian Journal of Communication, 18(3), 280-295.

Chanco, M. (2017). Asean at 50: will the regional bloc overcome its midlife crisis? Southeast Asia Globe. Retrieved on May 27, 2018, from http://sea-globe.com/willasean-overcome-midlife-crisis/

Chongkittavorn, K. (2015). Media still disconnected from the ASEAN Community. Reporting ASEAN. Retrieved on May 27, 2018, from http://www.aseannews.net/ media-still-disconnected-from-the-asean-community/

Das, S. (2012). A critical look at the ASEAN Economic Community scorecard. East Asia Forum. Retrieved on May 25, 2018, from http://www.eastasiaforum.org/2012/06/01/acritical-look-at-the-asean-economic-community-scorecard/

Desker, B. (2015). ASEAN integration remains an illusion. Center for Strategic and International Studies. Retrieved on May 27, 2018, from https:/www.csis.org/analysis/ pacnet-17-asean-integration-remains-illusion

Dosch, J. (2015). The ASEAN Economic Community: What stands in the way? Asia Pacific Issues, pp. 1-8. Retrieved on May 19, 2018, from https://www.eastwestcenter. org/publications/the-asean-economic-community-what-stands-in-the-way

Estella, P. (2018). Journalists' practices and perceived emotional stress in the time of 'weaponized' internet. Manuscript in preparation.

Gray, D. (2004). Doing research in the real world. Thousand Oaks, CA: Sage Publications, Inc. 
George, C. (2003). The internet and the narrow tailoring dilemma for 'Asian' democracies. The Communication Review, 6(3), 247-268.

George, S. (2009). What is development journalism? The Guardian. Retrieved May 27, 2018, from https:/www.theguardian.com/journalismcompetition/professional-whatis-development-journalism

Hahn, K., \& Iyengar, S. (2002). Consumer demand for election news: The horserace sells. Annual Meeting of the American Political Science Association, Boston. Retrieved on June 3, 2018, from https://pcl.stanford.edu/common/docs/research/iyengar/2002/ APSA2002.pdf

Hallin, D., \& Mancini, P. (2004). Comparing media systems: Three models of media and politics. Cambridge, UK: Cambridge University Press.

Hanitzsch, T. (2005). Journalists in Indonesia: Educated but timid watchdogs.Journalism Studies, 6(4), 493-508.

Hanitzch, T., Hanusch, F., Mellado, C., Anikina, M., Berganza, R., Cangoz, I., . . Yuen, E. (2011). Mapping journalism culture across nations: A comparative study of 18 countries. Journalism Studies, 12(3), 273-293.

Heydarian, R. (2015). Is ASEAN still relevant? The Diplomat. Retrieved on May 18, 2018, from https://thediplomat.com/2015/03/is-asean-still-relevant/

Hill, M., \& Kian, K. (1995). The politics of nation building and citizenship in Singapore. New York, NY: Routledge.

Hsiung, J. (1985). Human rights in Asia: A cultural perspective. New York, NY: Paragon House.

International Labor Organization, \& Asian Development Bank. (2014). ASEAN Community 2015: Managing integration for better jobs and shared prosperity. Bangkok, Thailand: International Labor Organization and Asian Development Bank.

Kalyango, Y., Hanusch, F., Ramaprasad, J., Skjerdal, T., Hasim, M., Muchtar, N., . . . Kamara, S. (2016). Journalists' Development Journalism Role Perceptions.Journalism Studies, 18(5), 1-19.

Karppinen, K. (2015). Review of the books Media commercialization and authoritarian rule in China, by D. Stockmann, and Freedom from the Press: Journalism and State Power in Singapore, by C. George. Political Communication, 331-344.

Kesavapany, K. (2015). Asean integration a work in progress, not an 'illusion'. The Straits Times. Retrieved May 17, 2018, from https:/www.straitstimes.com/opinion/ asean-integration-a-work-in-progress-not-an-illusion

Kurlantzick, J. (2014). The failures of the ASEAN Economic Community. Council on Foreign Relations. Retrieved from: https://www.cfr.org/blog/failures-asean-economic-community

Latif, A. (1996). Values: Idle concepts of realistic goal? In M. Masterton (Ed.), Asian values in journalism (pp. 152-157). Singapore: Asian Media, Information and Communication Center.

Lehmann-Jacobsen, E. (2017). Challenged by the state and the internet struggles for professionalism in Southeast Asian journalism. MedieKultur, 33(62), 18-34.

Lent, J. (1978). Mass communications in the third world: Some ethical considerations. Speech Communication Association Summer Conference on Intercultural/International Communication, Tampa, FL. Retrieved May 13, 2018, from http:// eric.ed.gov/ ERICDocs/data/ericdocs2sql/content_storage_01/0000019b/80/36/68/a4.pdf 
Loo, E. (2013). Bridging the cultural gaps in journalism education and training in Asia. Singapore: Konrad Adenauer Stiftung Media Asia Programme.

Marzuki, B. (2013). Free and independent: Fighting for what is right. In E. Loo (Ed.), Bridging the cultural gaps in education and training (pp. 145-148). Singapore: Konrad Adenauer Stiftung Media Asia Programme.

Massey, B., \& Chang, L. (2006). Locating Asian values in Asian journalism: A content analysis of web newspapers. Journal of Communication, 52(4), 987-1003.

Massola, J. (2018). Fears for independence as Phnom Penh Post sold to Malaysian investor. The Sydney Morning Herald. Retrieved on May 27, 2018, from https:// www.smh.com.au/world/asia/fears-for-independence-as-phnom-penh-post-sold-tomalaysian-investor-20180506-p4zdns.html

Media Ownership Monitor Cambodia. (2015). New players. Media Ownership Monitor Cambodia. Retrieved on May 29, 2018, from https://cambodia.mom-rsf.org/en/media/ detail/outlet/the-khmer-times/

Meixler, E. (2018). The sale of Cambodia's last independent newspaper pushes press freedom into peril. Time. Retrieved on May 19, 2018, from http://time.com/5269047/ cambodia-phnom-penh-post-newspaper/

Menon, J., \& Melendez, A. (2016). Realizing an ASEAN Economic Community: Progress and remaining challenge. The Singapore Economic Review, 681-701.

Menon, V. (1998). Forward. In A. Latif(Ed.), Walking the tightrope: Press freedom and professional standards in Asia (pp. iv-viii). Singapore: Asian Media, Information, and Communication Centre.

Mordecai, A. (2017). What is the future of integration and inequality in ASEAN? The Diplomat. Retrieved on May 17, 2018, from https://thediplomat.com/2017/09/whatis-the-future-of-integration-and-inequality-in-asean/

Nair, A. (2018). Success or failure: two experts debate the impact of ASEAN. Southeast Asia Globe. Retrieved on May 17, 2018, from http://sea-globe.com/has-asean-beena-success-or-a-failure/

Newman, N. (2009). The rise of social media and its impact on mainstream journalism: A study of how newspapers and broadcasters in the UK and US are responding to a wave of participatory social media, and a historic shift in control towards individual consumers. Reuters Institute for the Study of Journalism. Retrieved May 17, 2018, from https:// reutersinstitute.politics.ox.ac.uk/sites/default/files/2017-11/The $\% 20$ rise $\% 20$ of $\% 20$ social $\% 20$ media $\% 20$ and $\% 20$ its $\% 20$ impact $\% 20$ on $\% 20$ mainstream $\% 20$ journalism.pdf

Newman, N. (2016). Digital news report 2016. Reuters Institute for the Study of Journalism. Retrieved May 17, 2018, from https://reutersinstitute.politics.ox.ac.uk/sites/ default/files/research/files/Digital\%2520News\%2520Report\%25202016.pdf

$\mathrm{Ng}, \mathrm{C}$. (2015). ASEAN Community: What's that again? Reporting ASEAN. Retrieved on May 27, 2018, from http:/www.aseannews.net/asean-community-whats-that-again/ Pak, S. (1997). A reader in ethics. Phnom Penh: Cambodian Communication Institute. Reporters Without Borders. (2018). 2018 World Press Freedom Index. Retrieved on May 17, 2018, from https://rsf.org/en/ranking\#

Richstad, J. (2000). Asian journalism in the twentieth century. Journalism Studies, 1(2), 273-284.

Saldanha, J. (2009). The coding manual for qualitative researchers. Thousand Oaks, 
CA: SAGE Publications, Inc.

Shah, H. (1988). Development news on All India Radio: Assessment of quantity and quality. Journalism \& Mass Communication Quarterly, 65(2), 425-430.

Son, J. (2017a). Any takers for ASEAN news? ABS-CBN News. Retrieved on May 17, 2019, from http://news.abs-cbn.com/focus/02/25/17/any-takers-for-asean-news

Son, J. (2017b). 9 tips for surviving (and enjoying) reporting about ASEAN. Rappler. Retrieved on May 17, 2018, from https://www.rappler.com/thought-leaders/159221tips-surviving-enjoying-reporting-about-asean

Strauss, A., \& Corbin, J. (1998). Basics of qualitative research: Techniques and procedures for developing grounded theory. Thousand Oaks, CA: Sage Publications, Inc.

Stockmann, D. (2014). Media commercialization and authoritarian rule in China. Cambridge, UK: Cambridge University Press.

Tapsell, R. (2013). The media freedom movement in Malaysia and the electoral authoritarian regime. Journal of Contemporary Asia, 43(4), 614-635.

Tay, S., \& George, C. (1996). Asian media and elections: Frameworks in human rights and media systems. Asian Journal of Communication, 66(1), 9-29.

TODAY. (2016). TODAY's readership rises, bucking newspaper trend. Today. Retrieved from https://www.todayonline.com/singapore/todays-readership-rises-bucking-newspaper-trend

Tongwaranan, T. (2018). Inequality a growing challenge for rising ASEAN. Bangkok Post. Retrieved May 17, 2019, from: https://www.bangkokpost.com/business/ news/1455114/inequality-a-growing-challenge-for-rising-asean

Triputra, P. (2017). Indonesian journalist; After political reformation. European Scientific Journal, 248-270.

Willnat, L., Weaver, D., \& Choi, J. (2013). The global journalist in the 21st century: A cross-national study of journalistic competencies. Journalism Practice, 7(2), 163-183.

Wong, K. (2004). Asian-based development journalism and political elections: Press coverage of the 1999 general elections in Malaysia. The International Journal for Communication Studies, 66(1), 25-40.

Pauline Gidget Estella is an assistant professor at the University of the Philippines and a doctoral candidate at Technische Universität IImenau (Germany). She is also a journalism curriculum development consultant at the Philippine Department of Education. Her research interests lie in the fields of journalism education and journalism studies.

prestella@up.edu.ph.

Jonalyn Paz is a faculty member at the Far Eastern University. She is also the communication officer of the Philippine Department of Trade and Industry-Competitiveness Bureau. She specialises in development communication, development studies, media studies, climate change, and environmental social science. jpaz@feu.edu.ph 